\title{
Hydrated Sodium Calcium Aluminsilicate Protects Against Genotoxic Effects In Zeralenone-Treated Balb/C Mice
}

\author{
Samir Abbès ${ }^{a}$, , Jalila Ben Salah-Abbès ${ }^{a}$, Zouhour Ouanes ${ }^{b}$, Hassan Bacha ${ }^{b}$, \\ Omar Othman ${ }^{\mathrm{a}}$, Mosaad A. Abdel-Wahhab ${ }^{\mathrm{c}}$, Ridha Oueslati ${ }^{\mathrm{a}}$
}

a Laboratory of Environmental Immunology Microbiology and Cancerology, Faculty of Sciences Bizerte, 7021 Zarzouna, Tunisia. ${ }^{b}$ Laboratory of Research on Biologically Compatible

Compounds, Faculty of Dentistry, Rue Avicenne, 5019 Monastir, Tunisia. ${ }^{\circ}$ Food Toxicology \& Contaminants Dept. Nationa 1 Research Centre, Dokki, Cairo, Egypt.

\begin{abstract}
Zearalenone (ZEN) is a potent estrogenic metabolite mycotoxin produced by some Fusarium species. Few studies have been successfully employed to get rid of the ZEN contamination in foods. This study was conducted to evaluate the ability of hydrated sodium calcium aluminsilicate (HSCAS) to protect Balb/c mice against cytotoxicity and genotoxicity induced by ZEN. Mice were divided into nine experimental groups (12 mice/group) included the control group, the olive oil group, the groups treated orally with a single dose of HSCAS at doses level of 400,600 and $800 \mathrm{mg} / \mathrm{kg} \mathrm{b} . \mathrm{w}$, the group treated orally with a single dose of ZEN (40 mg/kg b.w), the group treated with ZEN plus HSCAS (400 mg/kg b.w), the group received Colchicin $(4 \mathrm{mg} / \mathrm{kg} \mathrm{bw})$ as a positive control for micronucleus assay and the group treated with mitomycin $\mathrm{C}(1 \mathrm{mg} / \mathrm{kg} \mathrm{bw})$ as a positive control for chromosome aberrations assay. Forty eight hours after treatment, the femur and tibia were dissected out and bone marrow was obtained for different assays. The results showed that ZEN was cytotoxic and genotoxic to Balb/c mice as indicated by the increase in frequencies of polychromatic erythrocytes micronucleated (PCEMN) and chromosomal aberrations in bone marrow cells. The simultaneous administration of HSCAS with ZEN resulted in a decrease of PCEMN number and chromosomal aberrations frequency and increased the polychromatic erythrocytes (PCE) in bone marrow cells compared with the ZEN alone group. It could be concluded that HSCAS itself was safe at different tested doses and efficient in the prevention of ZEN induced clastogenicity in mice at a dose level as low as $400 \mathrm{mg} / \mathrm{kg}$ b.w.
\end{abstract}

Keywords: HSCAS; Zearalenone; Micronuclei; Chromosome aberrations; Prevention.

\section{Introduction}

The contamination of food and feedstuff with mycotoxins represents a worldwide problem for both human and animals. These toxins originate from molds which grow on cereals and stored plants. Zearalenone (ZEN) is a phenolic rescorcyclic acid lactone, produced by certain Fusarium spp which infect cereals and grains, such as corn, oats, wheat and hay (Coulombe et al., 1993; Kuiper-Goodman et al., 1987). Although ZEN may be considered a phytoestrogen that is naturally occurring and found associated with grains (Nikov et al., 2000). ZEN has been implicated in numerous mycotoxicosis in farm animals and in humans (Etienne and Jammali 1982; Saenz de Rodriguez et al., 1985; Hussein and Brasel, 2001; Tomaszewski et al., 1998). There are also data on its capability to induce adverse liver lesions with subsequent development of hepatocarcinoma and pituitary tumours, indicating that these tissues should be considered as target organs for ZEN in vivo (Ouanes et al., 2005).

Most of the carcinogenic mycotoxins are genotoxic agents that produce chromosomal aberrations, micronuclei, sister 
chromatid exchange and chromosomal strand breaks, as well as DNA adducts in rodent and human cells (Wang et al., 1999). Recent studies have shown that ZEN induces DNA fragmentation, apoptosis and cell cycle arrest (Abid-Essefi et al., 2003). ZEN and possibly its derivatives impair oestrogen-controlled gene expression in cultured cells (Mayr, 1988) and decrease serum progesterone levels in vivo (Bacha et al., 1993). Lioi et al. (2004) reported that ZEN increases significantly structural chromosome aberrations and sister chromatid exchanges and reduces the mitotic index in bovine lymphocyte cultures. Moreover, Ouanes et al. (2005) demonstrated that ZEN induces different types of chromosomal aberrations in mouse bone marrow cells and induces micronuclei in a dosedependent manner in cultured Vero cells as well as in mouse bone marrow cells (Ouanes et al., 2003).

The novel technology applied for protecting animals against mycotoxicosis is the utilization of adsorbents agents mixed with feed which are supposed to bind efficiently mycotoxins in the gastrointestinal tract. Several reports have indicated that the phyllosilicate clay, HSCAS, which is currently used as an anti-caking agent for animal feeds, may prevent disease associated with aflatoxicosis in farm animals, including chickens, turkey poults, pigs and minks (Phillips et al., 1999). Moreover, HSCAS, bentonite and montmorillonite were found to protect laboratory animals from toxic and teratogenic effects of aflatoxin (Phillips et al., 1988; AbdelWahhab et al., 2002; Mayura et al., 1998). The adsorbabilities of bentonite and/or montmorillonite were found to be higher than other clay minerals. The reason may be due to the bigger surface area of these clays, which characteristically undergoes larger swelling (Philips et al., 1999). Up to $85 \%$ of toxic effects of aflatoxins such as liver damage and chromosomal aberrations were reversed by the addition of $0.5 \mathrm{~g}$ clay $/ \mathrm{kg}$ of contaminated diet (AbdelWahhab et al., 1998; 1999). Moreover, Wiles et al. (2004) suggested that neither calcium montmorillonite nor sodium montmorillonite clay, at relatively high dietary concentrations may influence mineral uptake or utilization in the pregnant rat. Recent studies indicated that bentonite can bind to ZEN in vitro and proposed this sorbent as a good candidate for detoxification of ZEN in foods (Bueno et al., 2005; Afriyie-Gyawu et al., 2005).

On the basis of these earlier findings, phyllosilicate clay minerals are now being added to feeds as 'mycotoxin binders' without appropriate in vitro and in vivo testing. Many of those may be non-selective in their action and may pose significant hidden risks due to interactions with nutrients and other important food-borne chemicals. Thus, our major objectives in the present work are in one hand to evaluate the effect of HSCAS alone on induction of micronuclei and chromosome aberrations on bone marrow cells of mice and on the other hand to investigate its eventual capacity to prevent such an effect induced by ZEN.

\section{Materials and methods}

\section{Chemicals and sorbent:}

ZEN (pure crystals), Acridine orange and Colchicin were purchased from Sigma Chemical Co. (St.Louis,MO, USA). Giemsa was obtained from Fluka (France). Mitomycin C was purchased from SanofiSynthelabo (France) and Vinblastin was obtained from Gedeon Richter Ltd. (France).Methanol and acetic acid (analysis grade) were purchased from Prolabo (France) and yeast powder was purchased from commercial local markets. Commercially HSCAS was obtained from Engelhard chemical Corporation (Cleveland,OH, USA). All other chemicals were of the highest purity commercially available.

\section{Animals:}

Six weeks old female Balb/c mice weighting $25 \pm 0.3 \mathrm{~g}$ (SEXUEL, St. Doulchard, France) were obtained from the Animal House of the Faculty Dentistry Medicine, Monastir, Tunisia. The mice were given a standard granulated chow and drinking water ad libitum. 


\section{Samir Abbès et al}

\section{Experimental design:}

Mice were distributed into nine treatment groups (12 mice/group) as following: group1, untreated control; group 2, olive oil group; group 3, treated orally with ZEN (40 $\mathrm{mg} / \mathrm{kg} \mathrm{b.w)} \mathrm{in} \mathrm{olive} \mathrm{oil;} \mathrm{groups} \mathrm{4,} \mathrm{5,} 6$ treated orally with HSCAS $(400,600$ and $800 \mathrm{mg} / \mathrm{kg}$ b.w respectively in distilled water; group 7 , treated orally with ZEN plus HSCAS (400 mg/kg b.w); group 8, treated orally with Colchicin $(4 \mathrm{mg} / \mathrm{kg}$ b.w) and considered as positive control group for micronucleus essay; group 9, treated orally with a single dose of Mitomycin C (1 $\mathrm{mg} / \mathrm{kg} \mathrm{bw}$ ) and considered as a positive control group for chromosome aberrations. Animals within treatment groups 1, 2, 3, 4, 5, 6 and 7 were divided into two subgroups $\mathrm{A}$ and $\mathrm{B}$ and were received their respective treatment in a single dose. All mice were sacrificed by cervical dislocation $48 \mathrm{~h}$. after the treatment.

\section{Mouse bone marrow micronucleus assay:}

Immediately after animals sacrificing, femur and tibia of the animals in subgroup $\mathrm{A}$ and Colchicin group were freed from adherent tissues and were dissected out. The bone marrow was sampled by injection of filtered foetal calf serum. The collected cells were centrifuged at $390 \mathrm{~g}$ for $5 \mathrm{~min}$, a little volume of supernatant was discarded then the cells were re-suspended in the remaining fluid. A small drop of the resuspended cell pellet was spread on a glass slide and fixed in absolute methanol for 5 min then air-dried for conservation at room temperature. The air-dried slides were stained for $15 \mathrm{~min}$ in phosphate buffer saline solution ( $0.15 \mathrm{M}$; $\mathrm{pH} 7.4)$ containing $10 \mu \mathrm{g} / \mathrm{ml}$ of acridine orange freshly prepared solution, rinsed in the same buffer solution for $15 \mathrm{~min}$ and allowed to dry in the dark at room temperature (Ouanes et al., 2003).

The slides were scored immediately under $1000 \times$ magnification using a fluorescent microscope (Nikon Eclipse E 400). Two thousand polychromatic erythrocytes (PCE) were examined from each animal and the number of polychromatic erythrocyte micronucleated (PCEMN) was recorded. PCEMN appears red including one or more yellow fluorescent corpuscles which are micronucleus (MN). Scoring of micronuclei was performed according to criteria described by Hayashi et al. (1983). These criteria are based essentially on the diameter and the shape of the MN. The number of PCEMN among 2000 PCE per mouse sample was determined to appreciate the induction of micronuclei. The ratio of NCE: PCE was determined in the same sample in order to evaluate any cytotoxic effect of ZEN and the potential protective effect of HSCAS against ZEN-induce cell damages in 1000 cells.

\section{In vivo chromosome aberration assay:}

Twenty-four hours before sacrifice, animals in subgroup B and mytomicin group were given a suspension of yeast powder $(100 \mathrm{mg} / 500 \mu \mathrm{l})$ to accelerate mitosis of bone marrow cells. Vinblastin $(200 \mu \mathrm{l} ; 250 \mu \mathrm{g} / \mathrm{ml})$ was injected into the animals $45 \mathrm{~min}$ before sacrificed in order to block dividing cells in metaphase.

The cells of bone marrow from femurs and tibia were collected, sustained with a hypotonic shock $(\mathrm{KCl} 0.075 \mathrm{M})$ and were fixed three times using methanolacetic acid according to the technique of Evans et al. (1960). The cells were spread on a glass slides that were blazed on a flame for $5 \mathrm{~s}$, then air-dried for conservation at room temperature and finally stained with a $4 \%$ dilution of Giemsa reagent in water for $15 \mathrm{~min}$. After coding of slides, the chromosomes of 100 cells stopped in metaphase were examined for chromosome abnormalities at a magnification of $1000 \times$ using an optical microscope, from each of three replicates (300 metaphases per dose level) for all experimental animals. Chromosome aberrations were identified according to criteria described by Savage (1975). Metaphases with chromosome break, gap, ring and centric fusion (robertsonian translocation) were recorded and expressed as percentage of total metaphases per group. 


\section{Statistical analysis:}

Micronucleus and cytotoxicity data were analyzed using Student's $t$-test. The differences in mean percentages between treated and control groups and among treated groups for numerical aberrations were evaluated using Chi-square test $(\chi 2$ test) (Waller and Duncan, 1969). All statements of significance were based on probability of $\mathrm{P} \leq 0.05$ and $\mathrm{P} \leq 0.01$.

\section{Results}

To evaluate the genotoxicity, the number of PCEMN among 2000 PCE were examined whereas the cytotoxicity was evaluated by using the number of PCE among 1000 total cells of bone marrow cells (PCE + NCE). The current study indicated that both Colchicin (the positive control) and ZEN induced genotoxicity as indicated by the significant increase $(\mathrm{P}<$ $0.05)$ in the number of PCEMN (68.00 \pm 1.63 and $27.33 \pm 1.08$ respectively) compared to the control group $(2.16 \pm 0.33)$. Animals treated with HSCAS alone (Fig 1) at the three tested levels $(400,600$ and 800 $\mathrm{mg} / \mathrm{kg} \mathrm{b.w)} \mathrm{had} \mathrm{no} \mathrm{significant} \mathrm{effect} \mathrm{on} \mathrm{the}$ number of PCEMN $(2.16 \pm 0.33,2.50 \pm$ 0.77 and $2.83 \pm 0.83$ respectively). Mice treated simultaneously with ZEN and HSCAS at a dose level of $400 \mathrm{mg} / \mathrm{kg}$ b.w showed a significant decrease in the elevation of PCEMN number $(6.5 \pm 1.09)$ resulted from ZEN treatment although these values were still higher than in the negative control groups (1.66 \pm 0.19 and $2.16 \pm$ 0.33 ) (Fig.2) since the reduction percentage reached $76 \%$.

Regarding the cytotoxicity, our results indicated that both Colchicin and ZEN treatment resulted in a significant decrease $(\mathrm{P} \leq 0.05)$ in the number of PCE $(212.33 \pm$ 3.19 and $228.14 \pm 18.53$ respectively) compared to the negative control group ( 386.58 \pm 2.63 ). Treatment with HSCAS alone at the three levels had a significant increase in the number of PCE $(484.35 \pm 15.12,470.54$ \pm 13.63 and $467.61 \pm 11.45$ respectively) (Fig 3). The combined treatment of ZEN plus HSCAS showed a significant improvement in PCE counts $(387.36 \pm 16.57)$ towards the normal values of the control group (Fig.4). The improvement percentage in PCE counts resulted in this group reached $69 \%$ of the number of PCE cells in bone marrow of ZEN alone treated group (Fig.4).

The results of structural aberrations included centric fusion, gaps, rings and Chromosomal breaks (Table 2) indicated that treatment with ZEN alone resulted in a significant increase in chromosome aberrations, mainly centric fusion, gaps (Fig. 5A) and chromosome breaks (Fig. 5B), in bone marrow cells. No significant differences were observed in the group treated with different dose levels of HSCAS alone compared to the controls. Treated with 400 $\mathrm{mg} / \mathrm{kg}$ b.w of HSCAS to ZEN-treated mice resulted to a significant decrease in the total chromosomal aberration induced by ZEN. The inhibition percentage in chromosomal aberrations of this group reached $78 \%$.

Table (1): Effect of HSCAS and its protective role on chromosomal aberrations in bone marrow cells of female Balb/c mice Zen-contaminated by orally rout

\begin{tabular}{|c|c|c|c|c|c|}
\hline \multirow[b]{2}{*}{ Groups } & \multicolumn{4}{|c|}{ Structural aberrations } & \multirow[b]{2}{*}{$\begin{array}{c}\text { Total } \\
\text { aberrations }\end{array}$} \\
\hline & Centric feusion & $\begin{array}{l}\text { Chromosomal } \\
\text { breaks }\end{array}$ & Gaps & Rings & \\
\hline Control water & $1.33 \pm 0.27^{a}$ & $1.66 \pm 0.27^{\mathrm{a}}$ & $0.00 \pm 0.00^{a}$ & $0.66 \pm 0.27^{a}$ & $3.65 \pm 0.47^{a}$ \\
\hline Control olive oil & $1.66 \pm 0.66^{D}$ & $1.33 \pm 0.00^{b}$ & $0.00 \pm 0.00^{6}$ & $0.66 \pm 0.00^{b}$ & $3.65 \pm 0.38^{D}$ \\
\hline Mitomycin C1 mg/kg & $32.66 \pm 0.88^{c}$ & $9.66 \pm 0.33^{c}$ & $3.33 \pm 0.33^{c}$ & $7.66 \pm 0.33^{c}$ & $53.31 \pm 1.08^{\mathrm{C}}$ \\
\hline $\mathrm{HSCAS} 400 \mathrm{mg} / \mathrm{kg}$ & $1.66 \pm 0.33^{b}$ & $1.33 \pm 0.33^{a}$ & $0.33 \pm 0.33^{\mathrm{d}}$ & $0.66 \pm 0.66^{a}$ & $3.98 \pm 0.96^{\mathrm{a}}$ \\
\hline HSCAS $600 \mathrm{mg} / \mathrm{kg}$ & $2.00 \pm 0.57^{c}$ & $1.00 \pm 0.57^{0}$ & $0.00 \pm 0.00^{6}$ & $0.33 \pm 0.33^{\mathrm{d}}$ & $3.33 \pm 0.85^{\mathrm{a}}$ \\
\hline HSCAS $800 \mathrm{mg} / \mathrm{kg}$ & $2.33 \pm 0.88^{\mathrm{C}}$ & $1.00 \pm 0.57^{0}$ & $0.00 \pm 0.00^{6}$ & $1.33 \pm 0.88^{\mathrm{e}}$ & $4.66 \pm 1.35^{\mathrm{a}}$ \\
\hline ZEN $40 \mathrm{mg} / \mathrm{kg}$ & $21.00 \pm 1.52^{\mathrm{d}}$ & $7.66 \pm 0.33^{d}$ & $3.00 \pm 0.57^{c}$ & $3.33 \pm 0.33^{\dagger}$ & $34.99 \pm 1.60^{\mathrm{d}}$ \\
\hline$H S C A S+Z E N$ & $2.33 \pm 0.88^{C}$ & $2.66 \pm 0.66^{e}$ & $0.00 \pm 0.00^{0}$ & $2.66 \pm 0.88^{g}$ & $7.65 \pm 1.40^{\mathrm{e}}$ \\
\hline
\end{tabular}

Within each column, means superscript with the same letter are not significantly different $(\mathrm{P}<0.05)$ 


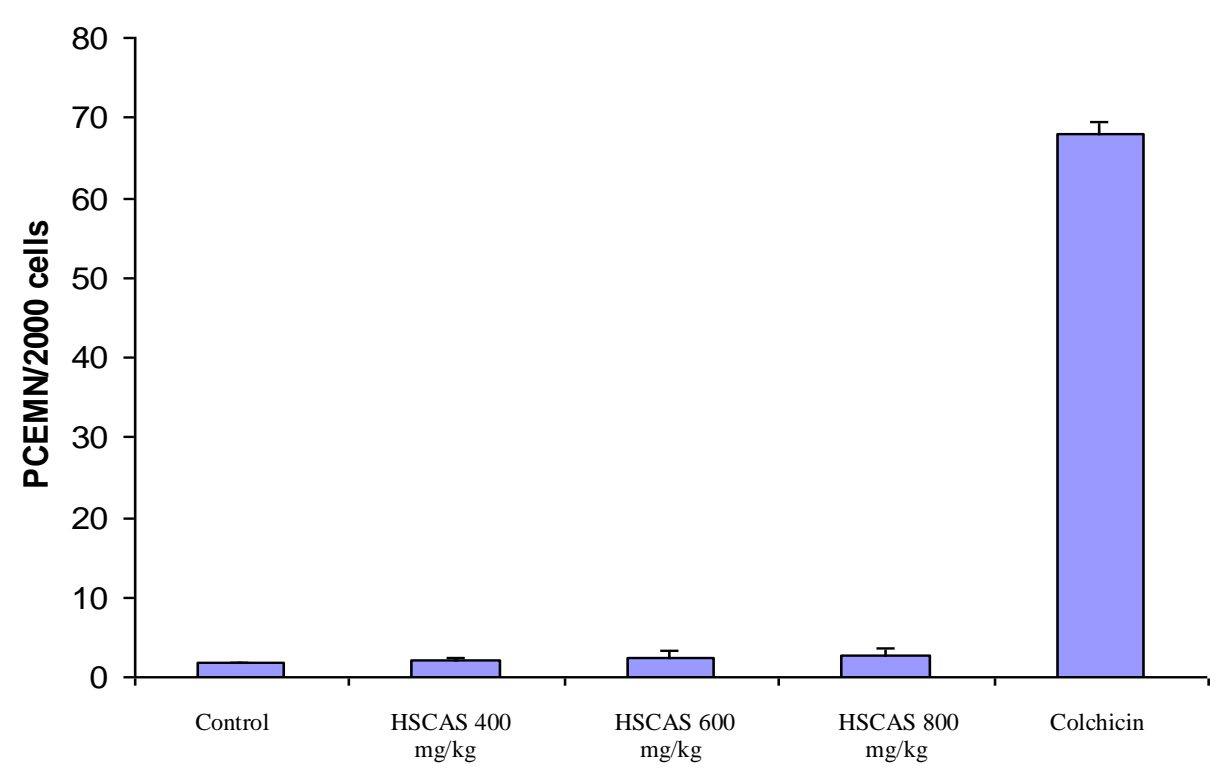

Fig.1. Effect of HSCAS and Colchicin on number of polychromatic erythrocyte micronucleated (PCEMN) in 2000 polychromatic erythrocyte cells (PCE) in bone marrow cells.

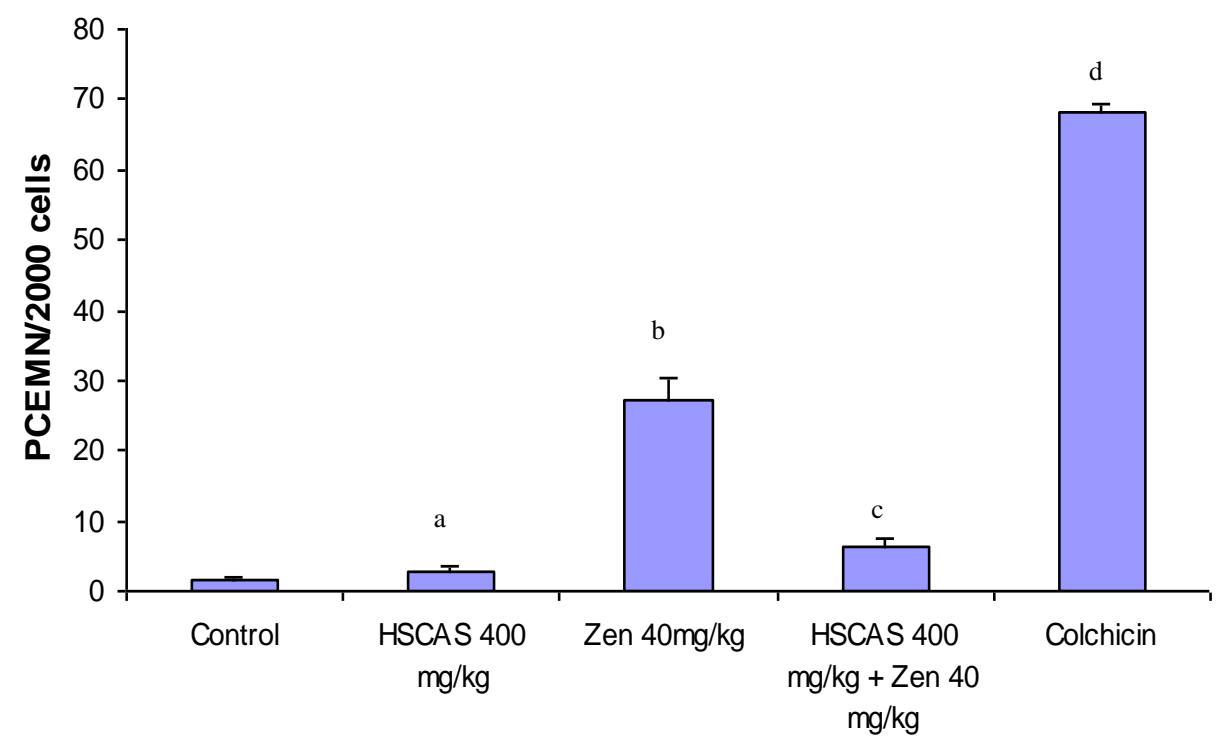

Fig.2. Protective role of HSCAS on ZEN-induced polychromatic erythrocyte micronucleated (PCEMN) in bone marrow cells in mice treated with ZEN Column superscript with different letters are significantly different $(\mathbf{P}<0.05)$. 


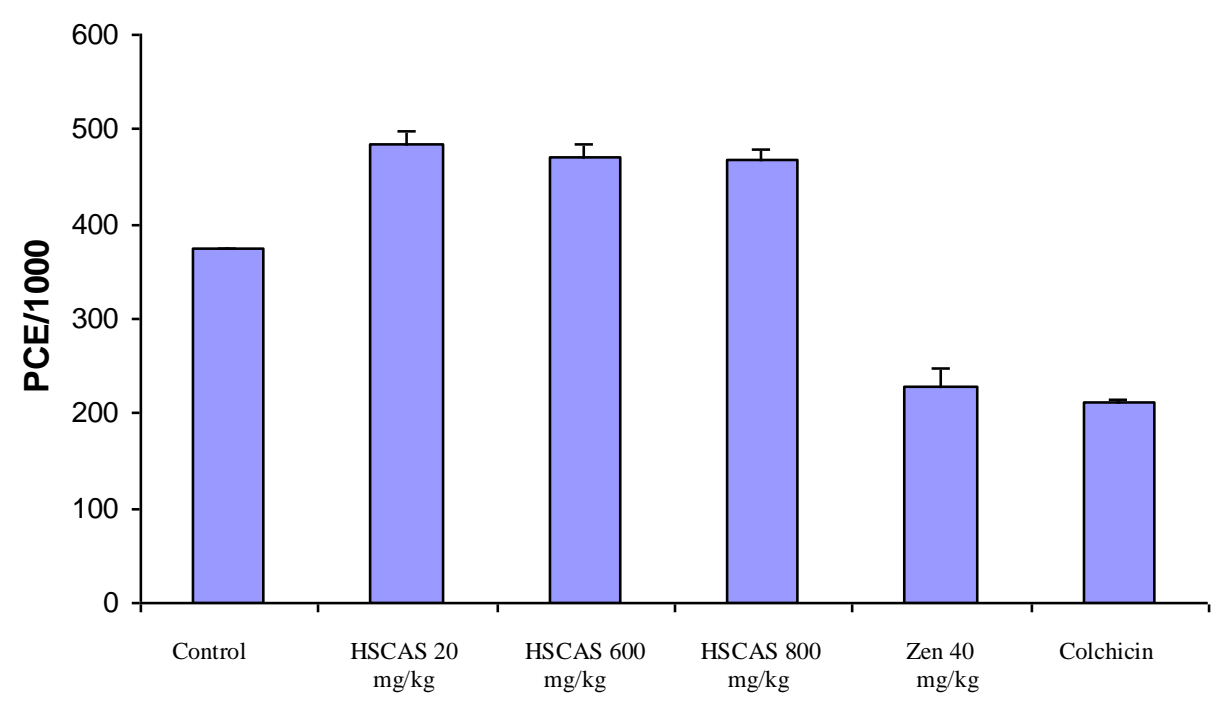

Fig. 3. Effect of HSCAS and ZEN on number of polychromatic erythrocyte in $\mathbf{1 0 0 0}$ polychromatic erythrocyte cells (PCE) and normochromatic erytrocytes cells (PCE + NCE) in bone marrow of mice.

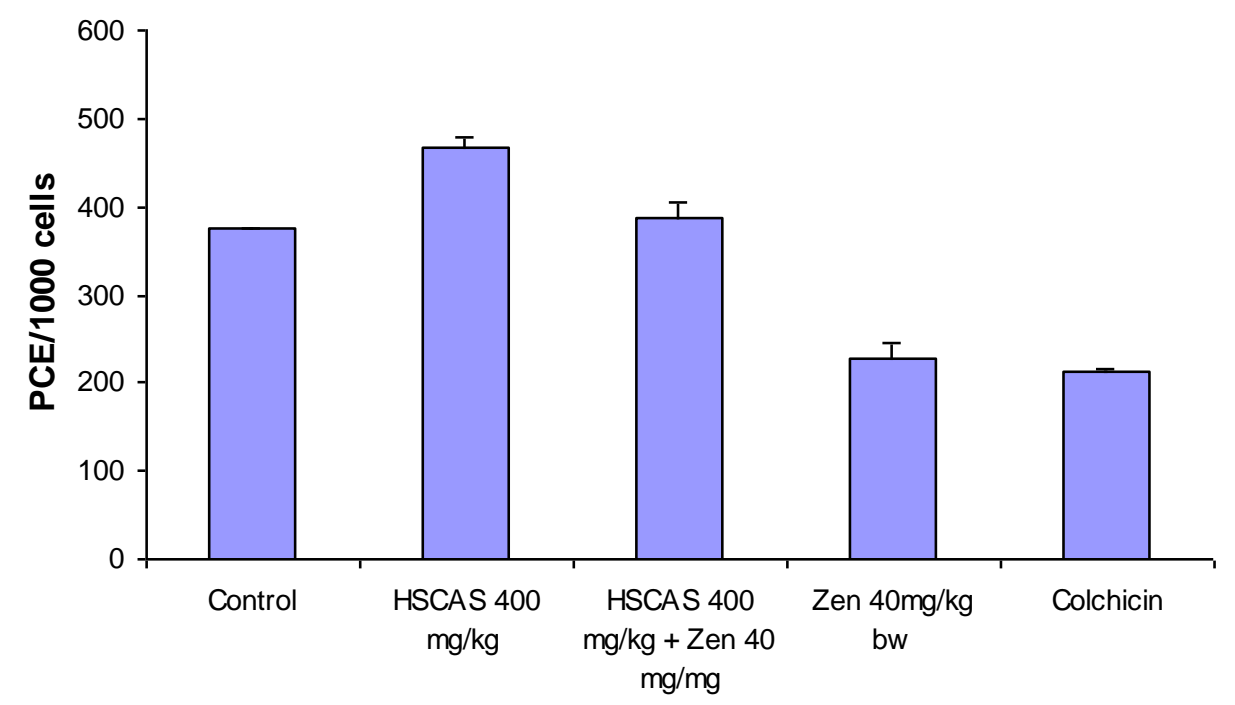

Fig.4. Number of polychromatic erythrocyte cells in 1000 polychromatic erythrocyte and normochromatic erytrocytes cells (PCE + NCE) in bone marrow of mice treated with ZEN alone or in combination with HSCAS. 

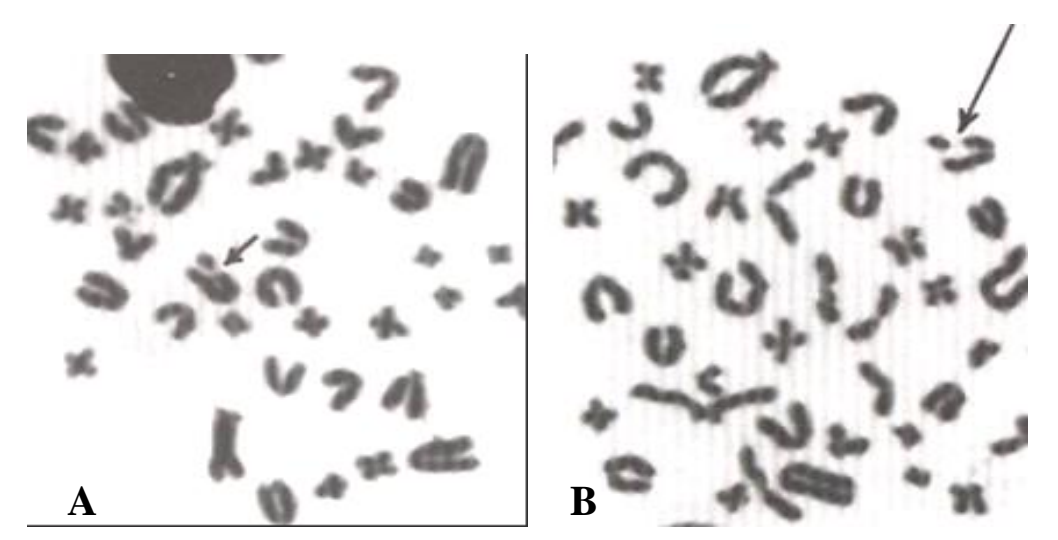

Fig. 5: Photomicrographs of metaphase spread showing (A) chromatid gap and (B) Chromatid break plaque.

\section{Discussion}

Fusarium mycotoxins occur worldwide in cereal grains and animal feeds and cause outbreaks of Fusarium mycotoxicosis in humans and animals resulted in severe effects of human health, veterinary care costs and livestock production (Hussein and Brasel, 2001). ZEN is one of the predominant contaminating mycotoxins in foodstuffs and grains in the highincidence area of malignant tumors (Ouanes et al., 2005). The presence of ZEN not only in animal feed but also in cow's meat and milk and human sera indicates continuous and widespread exposures of cattle and humans to these mycotoxins (KuiperGoodman et al., 1987; Breitholtz-Emanuelsson et al., 1993; Hagler et al., 1980). ZEN is absorbed quite easily from the intestinal tract and it is partially metabolized to $\alpha$-zearalenol and $\beta$-zearalenol by rumen protozoa (Olsen et al., 1989) and disrupter of the reproductive system (Bacha et al., 1993; Creppy et al., 2002). It also induces hematological and immunological toxic effects (Marin et al., 1996; Berek et al., 2001; Swamy et al., 2004; Karagezian et al., 2000) and other physiological toxic effects. Moreover, many studies have been reported that ZEN induces genotoxicity and cytotoxicity in vivo and in vitro (Ouanes et al., 2003; Hassen et al., 2005).

From this point of view, we evaluated the clastogenatic effect of HSCAS and its ability to protect ZEN-induced cell damage in vivo. In the present study, mice were treated orally with ZEN at a dose of $40 \mathrm{mg}$ $/ \mathrm{kg}$ b.w. The selective dose of ZEN and HSCAS were based on our previous work (Abbès et al., 2006). Our results indicated that ZEN induced genotoxicity in mice as indicated by the significant increase in the frequencies of PCEMN and chromosomal aberrations in bone marrow. The clastogenicity of ZEN may be related to the formation of adducts that disturb DNA replication, resulting in chromosomal aberrations. According to Abid-Essefi et al. (2004) ZEN reduced cell viability correlated to cell cycle perturbation, inhibits protein and DNA syntheses and increases MDA formation. Such results indicated that cytotoxicity and oxidative damage are additional mechanisms of ZEN mediated toxicity. ZEN also induces DNAadduct formation in mouse tissues and SOS repair process in lysogenic bacteria (Chekir-Ghedira et al., 1998). In the same regards, Abid-Essefi et al. (2003) concluded that ZEN induces DNA fragmentation resulting in DNA laddering patterns, apoptosis and cell cycle arrest.

The current study shows that HSCAS did not have negative impact on the overall health at the different tested doses. Similar results were described by Mayura et al. (1998) and indicated that HSCAS given by gavage route to pregnant rats was not toxic neither in maternal parameters (mortality, body weight, feed intake, litter size and histological picture of liver and kidney), nor 
in developmental parameters (embryonic resorptions and foetal body weights). Moreover, Wiles et al. (2004) suggested that neither calcium montmorillonite nor sodium montmorillonite clay, at relatively high dietary concentrations, influence mineral uptake or utilization in the pregnant rat. Generally, the addition of sorbent was able to protect mice from clastogenic effects of ZEN. Indeed, animals treated with HSCAS in combination with ZEN clearly showed a reversion of the cytotoxicity and the genotoxicity induced by ZEN. This was not strange since HSCAS and other clays have been largely described to reverse adverse effects caused by mycotoxins. In this regards, Abdel-Wahhab et al. (1998) reported that HSCAS and bentonite are effective in the protection against aflatoxin $\mathrm{B}_{1}$ and prevent its toxic and clastogenic effects which was reflected by ameliorating the alterations in serum biochemical parameters and suppressing chromosomal aberrations.

As demonstrated in the present study, addition of HSCAS to ZEN resulted in a significant decrease in the number of PCEMN and chromosomal aberrations. This can be explained by a mechanism suggested earlier by Phillips et al. (1999) which appears to involve sequestration of ZEN in the gastrointestinal tract and chemisorptions (tight binding) to HSCAS, resulting in the reduction of toxin bioavailability. This hypothesis was supported also by the results described by Bursian et al. (1992) who demonstrated that the addition of HSCAS to the diet protects mink against the effects of ZEN on the reproductive process. On the other hand, ZEN was found to be able to bind efficiently with other sorbent materials (i.e) montmorillonite and bentonite (Lemke et al., 2001). Afriyie-Gyawu et al. (2005) suggested that the addition of either activated carbon or hectorite effectively decreased the effects of ZEN on reproductive toxicity in Hydra attenuate assay. Furthermore, HSCAS can be considered as a good candidate for the prevention against aflatoxin-induced cytogenetic effects (Abdel-Wahhab et al., 2002) or for the detoxification of ZEN-contaminated foods (Abbès et al., 2006).
The treatment with HSCAS resulted in an inhibition in micronuclei (76.2\%), PCE death cells (69\%) and chromosomal aberration $(78 \%)$ in bone marrow of mice received ZEN. These findings concluded that HSCAS has a strong binding capacity to ZEN resulting not only in a decrease in the bioavailability of ZEN in the gastrointestinal tract but may be also in a subsequent reduction in the distribution to different organs. This may be due to the complex structure of HSCAS, which incre-ases the adsorption of organic compounds, pathogen agents including rotavirus, Escherchia coli, Camylobacter, bile salts and nondigested sugars in each of its layers (Fushiwaki et al., 2001; Droy et al., 1986). Many studies (Moore et al., 1997; Sposito et al., 1999; Abdel-Wahhab et al., 2005) reported that phyllosilicate clays are composed of layers of lattice silicates and chain silicates differentiated by the number of tetrahedral and octahedral sheets that have combined. These silicates are essentially composed of repeating layers of divalent or trivalent cations can be Aluminas, Magnesium, Iron etc. held in octahedral coordination with oxygen and hydroxyl groups and silicas that are tetrahedrally coordinated with oxygen and hydroxyl groups. In general, HSCAS like other phyllosilicate clays may possess four types of active binding sites: those located at basal planes within interlayer channels, those located on the surface and at the edges of clay particles and siloxane cavity in the basal plane of a tetrahedral sheet.

In conclusion, the present data indicated that ZEN has a cytotoxic and genotoxic effects in bone marrow of mice after $48 \mathrm{~h}$. of the treatment with a single dose and HSCAS was effective in the prevention of these clastogenic effects. More importantly the clay itself was found to be safe at a dose as high as $800 \mathrm{mg} / \mathrm{kg}$ b.w.

\section{Acknowledgements}

This research was supported by the Ministère tunisien de la Recherche Scientifique et de la Technologie (Unite d'Immunologie-Microbiologie 
Environnementale et Cancerologie: IMEC) and (Laboratoire de Recherche sur les Substances Biologiquement Compatibles: LRSBC).

\section{References}

1. Abbès $\mathbf{S}$, Ouanas $\mathbf{Z}$, Ben Salah-Abbès $\mathbf{J}$, Houas Z, Oueslati R, Bacha H, Othman O. (2006): The protective effect of hydrated sodium calcium aluminosilicate against haematological, biochemical and pathological changes induced by zearalenone in mice. Accepted for publication in Toxicon.

2. Abdel-Wahhab M A, Nada S A, Amra $\mathbf{H}$ A. (1999): Effect of aluminosilicateand bentonite on aflatoxin-induced developmental toxicity in rats. J. Appl. Toxicol. 19; 199-204.

3. Abdel-Wahhab M A, Nada S A, Farag I M, Abbas N F, Amra H A (1998): Potential of protective effect of HSCAS and bentonite against dietary aflatoxicosis in rat: with special reference to chromosomal aberrations. Nat. Toxins 6; 211-218.

4. Abdel-Wahhab M A, Nada S A, Khalil F A (2002): Physiological and toxicological responses in rats fed aflatoxin-contaminated diet with or without sorbent materials. Anim. Feed Sci. Technol. 40; 1-11.

5. Abdel-Wahhab M A, Aly S E (2005): Antioxidant Property of Nagilia Sativa (Black cumin) and Syzygium Aromaticum (Clove) Rats during Aflatoxicosis. J. Appl. Toxicol. 25; 218-223.

6. Abid-Essefi S, Baudrimont I, Hassen W, Ouanes Z, Mobio T A, Ananeb R, Creppy E E, Bacha H (2003): DNA fragmentation, apoptosis and cell cycle arrest induced by zearalenone in cultured DOK, Vero and Caco-2 cells: prevention by Vitamin E. Toxicology 192; 237-248.

7. Abid-Essefi S, Ouanes Z, Hassen W, Baudrimont I, Creppy E E, Bacha $H$ (2004): Cytotoxicity, inhibition of DNA and protein syntheses and oxidative damage in cultured cells exposed to Zearalenone. Toxicol. In Vitro 18; 467-474.

8. Afriyie-Gyawu E, Wiles M C, Huebner $\mathbf{H}$ J, Richardson M B, Fickey C, Phillips T D (2005): Prevention of zearalenoneinduced hyperestrogenism in prepubertal mice. J. Toxicol. Environ. Health A. 12; 353-368.

9. Bacha H, Chekir L, Ellouz F, Hadidane R, Creppy E E (1993): Effects of zearalenone on fertilisation and gestation in rats.
In: Scudamore, K.A. (Ed.), Proceedings of the UK Workshop on Occurrence and Significance of Msycotoxin. Central Sciences Laboratory, The University of West London, London, pp. 258-262.

10. Berek L, Petri I. B, Mesterhazy A, Teren J, Molnar J (2001): Effects of mycotoxins on human immune functions in vitro. Toxicol. In Vitro 15; 25-30.

11. Breitholtz-Emanuelsson A, Olsen $\mathbf{M}$, Oskarsson A, Palminger I, Hult K (1993): Ochratoxin A in cow's milk and in human milk with corresponding human blood samples. J. AOAC Int. 76; 842-846.

12. Bueno D J, Di Marco L, Oliver G, Bardon A (2005): In vitro binding of zearalenone to different adsorbents, J. Food Prot. 68; 613-615.

13. Bursian S J, Aulerich R J, Cameron J K, Ames N K, Steficek B A (1992): Efficacy of hydrated sodium calcium aluminosilicate in reducing the toxicity of dietary zearalenone to mink. J. Appl. Toxicol. 12; 85-90.

14. Chekir-Ghedira L, Maaroufi K, Zakhama A, Ellouz F, Dhouib S, Creppy E E, Bacha H (1998): Induction of a SOS repair system in lysogenic bacteria by zearalenone and its prevention by Vitamin E. Chem. Biol. Interact. 113; 15-25.

15. Coulombe Jr R A (1993):Biological action of mycotoxins, J. Dairy Sci. 76 880-891.

16. Creppy E E (2002): Update of survey, reglation and toxic effects of mycotoxins in Europe. Toxicol. Lett. 127; 19-28.

17. Droy M T, Navetat H, Espinasse J L (1986): Diarrhes neo-natales a rotavirus du veau: effet protecteur de la smectite. Congres Mondial de Gastroenterologie Sao Paulo. 5-13 September.

18. Etienne M, Jemmali M (1982): Effects of Zearalenone (F2) on oestrus activity and reproduction in gilts, J. Anim. Sci. 55; 1-10.

19. Evans E P, Breckon G, Ford C E (1960): An air drying method for meiotic preparation from mammalian tests, Cytogenetics 3; 613-616.

20. Fushiwaki Y, Urano K (2001): Adsorption of pesticides and their biodegraded products on clay minerals and soils, J. Health Sci. 47; 429-432.

21. Hagler W M, Danko G, Horvath L, Alyusik M, Mirocha C (1980): Transmission of zearalenone and its metabolite into ruminant milk, Acta Vet. Acad. Sci. Hung. 28; 209-216.

22. Hassen W, El Golli E, Baudrimont I, Mobiob A T, Ladjimi M. M, Creppy E E, Bacha H (2005): Cytotoxicity and Hsp 70 
induction in Hep G2 cells in response to zearalenone and cytoprotection by sublethal heat shock, Toxicol. 207; 293-301.

23. Hayashi $\mathbf{M}$, Sofuni $\mathbf{T}$, Ishidate $\mathbf{J r} \mathbf{M}$ (1983): An application of Acridine Orange fluorescent staining to micronucleus test, Mutat. Res. 120; 241-247.

24. Hussein H S, Brasel J M (2001): Toxicity, metabolism and impact of mycotoxins on humans and animals, Toxicology 167; 101134.

25. Karagezian M K (2000): Effect of the mycotoxin zearalenone on the metabolism of membrane phospholipids of rat lymphocytes. Ukr. Biokhim. Zh. 72; 105-109.

26. Kuiper-Goodman $\mathbf{T} \mathbf{P}$, Scoot $\mathbf{M}$, Watanabe H (1987): Risk assessment of the mycotoxin Zearalenone, Regul. Toxicol. Pharmacol. 7; 253-306.

27. Lemke S L, Mayura K, Reeves W R, Wang N, Fickey C, Phillips T D (2001): Investigation of organophilic montmorillonite clay inclusion in zearalenone-contaminated diets using the mouse uterine weight bioassay. J. Toxicol. Environ. Health A. 62; 244-258.

28. Lioi M B, Santoro A, Barbieri R, Salzano S, Ursini M V (2004): Ochratoxin A and zearalenone: a comparative study on genotoxic effects and cell death induced in bovine lymphocytes, Mutat. Res. 557; 19-27.

29. Marin L, Murtha J, Dong W, Pestka J J (1996): Effects of mycotoxins on cytokine production and proliferation in EL4 thymoma cells. J. Toxicol. Environ. Health 48; 379-396.

30. Mayr V E (1988): Oestrogenic-controlled gene expression in tissue culture cells by zearalenone. FEBS Lett. 239; 223-226.

31. Mayura K, Abdel-Wahhab $\mathbf{M}$ A, McKenzie K S, Sarr A B, Edwards J F, Naguib Kh, Phillips T D (1998): Prevention of maternal and developmental toxicity in rats via dietary inclusion of common aflatoxin sorbents: potential for hidden risks. Toxicol. Sci. 41; 175-182.

32. Moore D M,Reynolds R C (1997): X-Ray Diffraction and Identification and Analysis of Clay Minerals Oxford Univ. Press, New York.

33. Nikov $\mathbf{G} \mathbf{N}$, Hopkins $\mathbf{N}$, Boue $\mathbf{S}$, Alworth W L (2000): Interactions of dietary estrogens with human estrogen receptors and the effect on estrogen receptorestrogen response element complex formation. Environ. Health Perspect. 108; 867-872.

34. Olsen M (1989) Metabolism of zearalenone in farm animals, in: J. Chelkowski
(Ed.), Fusarium: Mycotoxins, Taxonomy and Pathogenicity, Elsevier, Amsterdam pp. 167-177.

35. Ouanes Z, Abid S, Ayed I, Anane R, Mobio T, Creppy E E, Bacha H (2003): Induction of micronuclei by Zearalenone in Vero monkey kidney cells and in bone marrow cells of mice: protective effect of Vitamin E. Mutat. Res. 538; 63-70.

36. Ouanes Z, Ayed-Boussema I, Baati T, Creppy E E, Bacha H (2005): Zearalenone induces chromosome aberrations in mouse bone marrow: preventive effect of 17-estradiol, progesterone and Vitamin E. Mutat. Res. 565; 139-149.

37. Phillips T D (1999): Dietary clay in the chemoprevention of aflatoxin-induced disease. Toxicol. Sci. 52; 118-126.

38. Phillips T D, Kubena L F, Harvey R B, Taylor D S, Heidelbaugh N D (1988): Hyderated sodium calcium aluminosilicate: a high affinity sorbent for aflatoxin. Poult. Sci. 67; 243-247.

39. Saenz de Rodriguez C A, Bougiovanni A M, Conde de Borrego L (1985): An epedemic of precocious development in Puerto Rican children. J. Pediatr. 107; 393-396.

40. Savage J R K (1975): Classification and relationship of induced chromosomal structural changes.J. Med. Genet. 12; 103-122.

41. Sposito G, Skipper N T, Sutton R, Park S,Soper A K,Greathouse J A (1999): Surface geochemistry of the clay minerals. Proc.Natl.Acad.Sci. USA 96 pp.3358-3364.

42. Swamy H V, Smith T K, Karrow N A, Boermans H J (2004): Effects of feeding blends of grains naturally contaminated with Fusarium mycotoxins on growth and immunological parameters of broiler chickens. Poult. Sci. 83; 533-543.

43. Tomaszewski J, Miturski R, Semczuk A, Kotarski J, Jakowicki J (1998): Tissue Zearalenone concentration in normal, hyperplastic and neoplastic human endometrium. Ginekol. Pol. 69; 363-366.

44. Waller $\mathbf{R}$ A, Duncan D B, Bayes A (1969): Rule for the symmetric multiple comparison problems. J. Am. Stat. Assoc. 64; 1484-1503.

45. Wang J S, Groopman J D (1999): DNA damage by mycotoxins. Mutat. Res. 424; 167-181.

46. Wiles M, Huebner H, Afriyie-Gyawu E, Taylor R, Bratton G, Phillips T D (2004): Toxicological evaluation and metal bioavailability in pregnant rats following exposure to clay minerals in the diet. J. Toxicol. Environ. Health A. 67; 863-874. 
مادة الهيدريتيد صوديوم كالسيوم ألومينوسيليكات تحمي من التأثيرات الوراثية السامة للزير الينون في الفئران

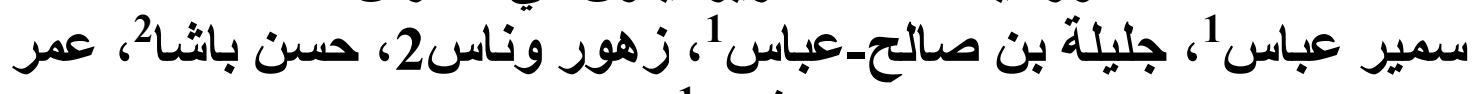
عثمان،

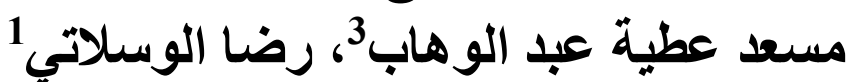

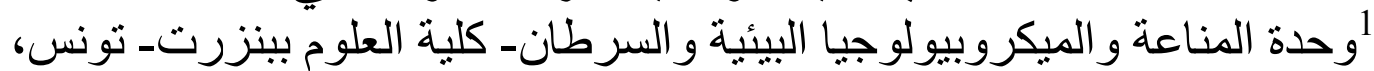

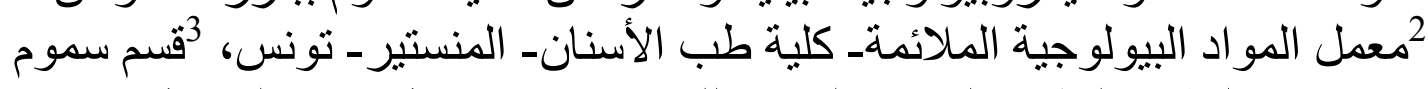

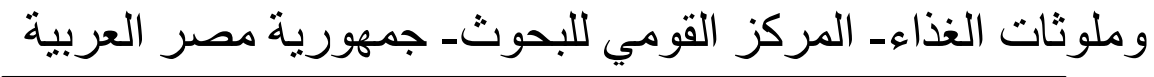

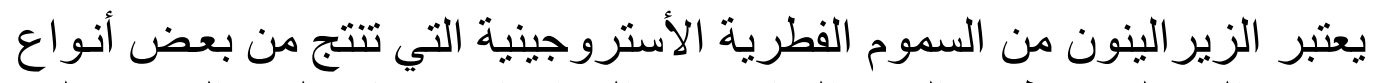

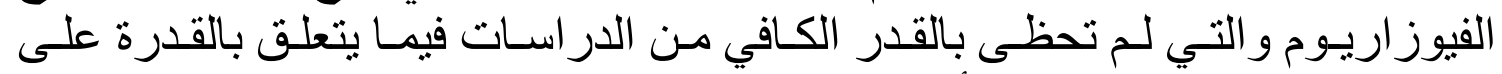

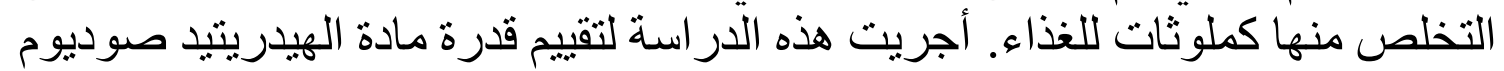

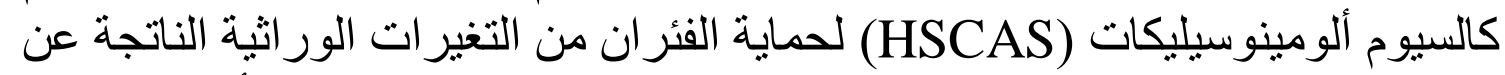

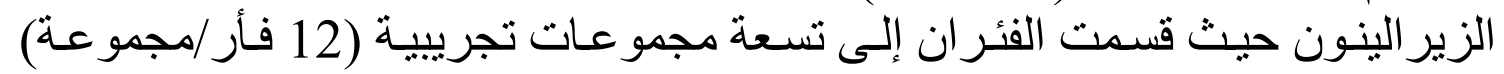



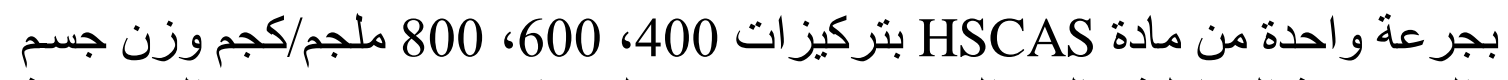

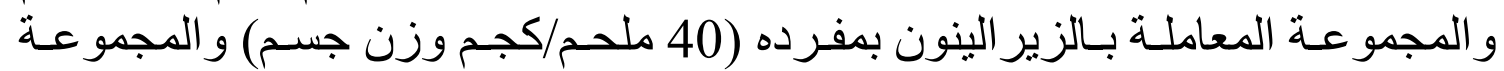

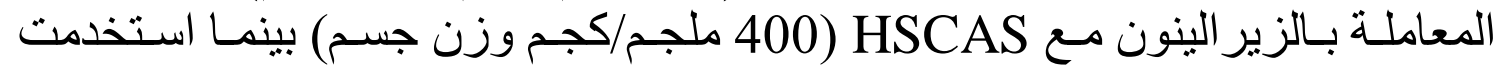



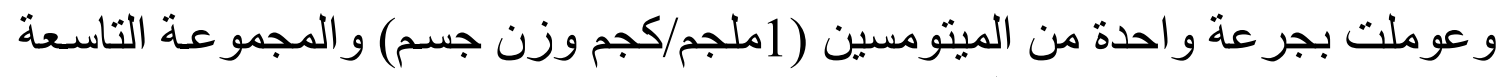

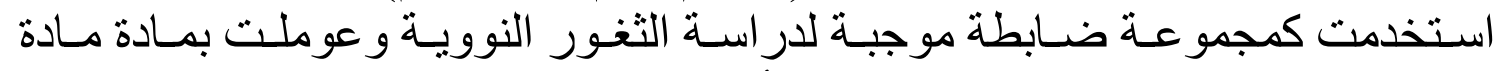

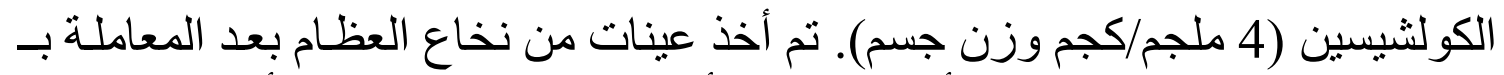

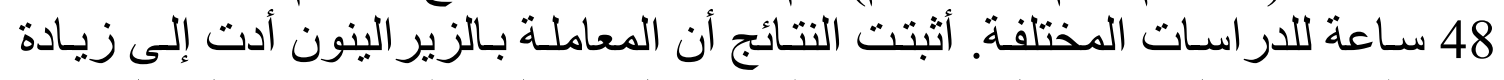

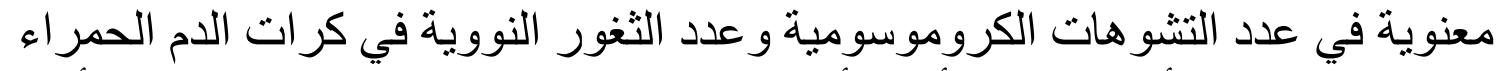
النخاع العظام. كما أثتبت النتائج أيضا أن المعاملة بمادة

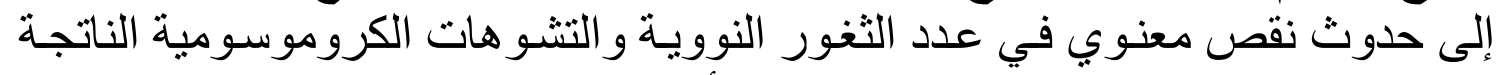

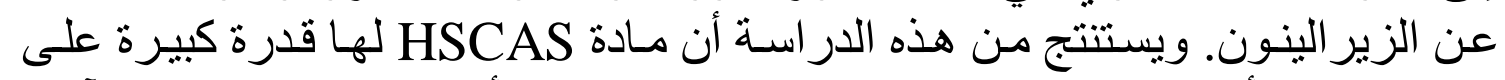



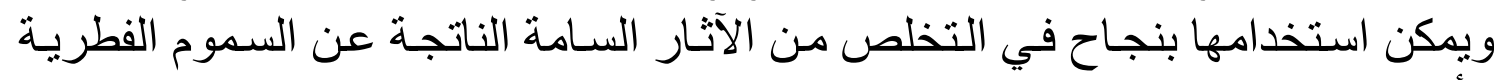



